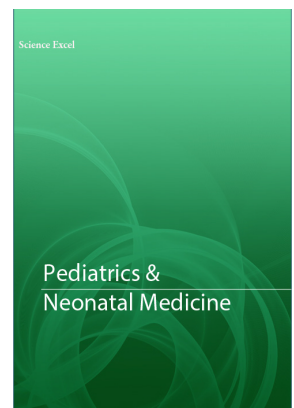

Correspondence

Husam Salama

Senior Neonatologist, Women's Wellness and Research Center, Hamad Medical City, Hamad Medical Corporation, Po Box 3050, Qatar

- Received Date: 26 Nov 2020

- Accepted Date: 10 Dec 2020

- Publication Date: 15 Dec 2020

Copyright

(C) 2020 Science Excel. This is an openaccess article distributed under the term of the Creative Commons Attribution 4.0 International license.

\title{
Socioeconomic Risk Factors for Preterm Birth in Qatar: A Population-based Study
}

\author{
Sayad Salama, Husam Salama, Mai Al Qubaisi, Hilal Al Rifai, Sawsan Al Obaidly
}

Senior Neonatologist, Women's Wellness and Research Center, Hamad Medical City, Hamad Medical Corporation, Qatar

\begin{abstract}
Objectives: Prematurity is considered the second leading cause all over the world of the neonatal morbidity and mortality. The aim is to review the socioeconomic determinants of preterm birth (PTB) compared to term births among the population resident in state of Qatar.

Methods: This was a retrospective data analysis of 59,308 births. Data were retrieved from a Populationbased cohort Study retrieved from PEARL-Peristat maternal newborn registry for 2011, 2012, 2017, and 2018. We compared the preterm births (delivery $<37$ weeks) and the term births (delivery $\geq 37$ weeks) against different factors. Each factor was divided into optimum socio-economic environment (control) and less optimum environment risk exposed group (risk case). The socioeconomic factors are maternal nationality, religion, level of education, mother's occupation, family income, housing, consanguinity, early childbearing, high-risk pregnancy, smoking, assisted conception, antenatal care, and place of delivery.

Results: We enrolled 5430 preterm newborns and 53878 born at full-term respectively. The prevalence of preterm birth was $9 \%$. There was more preterm birth among Qatari women than non-Qatari $10.4 \%$ $(1796 / 17115)$ versus non-Qatari 8.6\% (3634/42193) with $\mathrm{p}<0.0001$. High risk pregnancy was more likely associated with preterm birth, $12 \%$ versus $8.5 \%$ in normal pregnancy with $\mathrm{P}<0.001$, and CI $=1.15-1.31$ and $\mathrm{OR}=1.23$. Lack of antenatal care was strongly associated with preterm birth with $15 \%$ vs $8.6 \%$. Preterm birth was 6 times likely to occur with assisted conception $38 \%$ vs $8.5 \%$ in normal conception with $\mathrm{P}$ value $<0.0001$ and $\mathrm{CI}=6.11-7.34$. Mothers with high gravidity were less likely to deliver prematurely $9.4 \%$ vs $13.6 \%$ in gravidity less than 4 with $\mathrm{OR}=0.4$ and $\mathrm{P}$ value $<0.0001$ Housewife was less likely to deliver prematurely $\mathrm{p}<0.001, \mathrm{OR}=1.23$ and $\mathrm{CI}=1.15-1.31$. Maternal smoking

None of father education, poor housing, religion, level of maternal education, family income, early childbearing, or marital status were of significant impact on increased risk of Preterm birth.

Conclusions: In our population, we identified several factors associated with preterm births, the most important is Lack of antenatal care, assisted conception and working mothers.
\end{abstract}

\section{Introduction}

It is estimated that $5-18 \%$ of pregnancies end with preterm births (before 37 weeks of gestation) [1]. Prematurity is considered the second leading cause of neonatal morbidity and mortality [2,3]. Regardless of birth weight and/or gestational age, newborns are fragile, particularly when birth occurs before term. Preterm births are at risk of serious short-, medium-, and long-term consequences. Also, preterm infants are at risk of developing chronic non-communicable diseases in the short and long term. Compared with those infants born before the 37th week of pregnancy, infants born prematurely have a higher risk of serious disability and prenatal mortality and morbidity [4-6]. It has been proposed that early implementation of preventive interventions among pregnant women who are at high risk for preterm birth (PTB) could substantially reduce the amount of morbidity and mortality among newborns [7].

Here, we aimed to determine the socioeconomic factors associated with preterm births. This study provides data on the extent of the problem in Qatar and the associated risk factors. Such data will help health personnel to screen for those factors during the follow-up of preterm infants.

\section{Materials and Methods}

TThis was a retrospective data analysis of 59,308 births. Data were retrieved from a Population-based cohort Study retrieved from PEARL-Peristat maternal newborn registry for 2011, 2012, 2017, and 2018. We compared the preterm births (delivery $<37$ weeks) and the term births (delivery $\geq 37$ weeks) against different factors. Each factor was divided 
into optimum socio-economic environment (control) and less optimum environment (risk factor). The socioeconomic factors are maternal nationality ( national vs residents), religion ( Muslim vs non-Muslim), level of education(High vs non), mother's occupation(housewife vs working), family income(high Vs low), housing(separate vs Shared), consanguinity(no vs Yes), early childbearing(high vs Low), high-risk (no vs yes) pregnancy, smoking (no vs Yes), assisted conception (No vs Yes), antenatal care (Yes vs No), and place of delivery ( Referral vs secondary).

Data processing and analysis: The data was retrieved from the PEARL-Peristat newborn-maternal registry developed for 2011, 2012, 2017, and 2018. The Peristat registry was funded by the Qatar National Research Fund (QNRF). Statistics include the Fisher and mid-p exact tests, chi-squares, odds ratio, and maximum likelihood odds ratio estimate. P-values $<0.05$ were considered significant with $95 \%$ confidence interval. Quantitative determinants using an independent t-test to compare means among maternal and neonatal outcome categories using independent t-test Mann Whitney for skewed data.

\section{Results}

We enrolled 5430 preterm newborns and 53878 born at full-term respectively. The prevalence of preterm birth was 9\%. There were more preterm birth among Qatari women than non-Qatari 10.4\% (1796/17115) versus non-Qatari 8.6\% (3634/42193) with $\mathrm{p}<0.0001$. High risk pregnancy was more likely associated with preterm birth $\mathrm{P}<0.001$, and CI $=1.15-1.31$ and $\mathrm{OR}=1.23$. Lack of antenatal care was strongly associated with preterm birth with $15 \%$ vs $8.6 \%$. Preterm birth was 6 times likely to occur with assisted conception $38 \%$ vs $8.5 \%$ in normal conception with $\mathrm{P}$ value $<0.0001$ and $\mathrm{CI}=6.11$ 7.34. Mothers with high gravidity were less likely to deliver prematurely $9.4 \%$ vs $13.6 \%$ in gravidity less than 4 with OR= 0.4 and $\mathrm{P}$ value $<0.0001$. Housewife were less likely to deliver prematurely $\mathrm{p}<0.001, \mathrm{OR}=1.23$ and $\mathrm{CI}=1.15-1.31$. Maternal smoking group showed $12 \%$ rate of preterm birth versus nonsmoking $8 \%$. (Table 1 )

None of religion, level of maternal education, family income, and early childbearing or marital status was of impact on increased risk of Preterm birth. (Table 2).

Table 1. Significant Socio-economic factors.

\begin{tabular}{|c|c|c|c|c|c|}
\hline \multirow{3}{*}{ Socio-demographic characteristics } & \multicolumn{4}{|c|}{ Birth } & \multirow{3}{*}{$\begin{array}{c}\text { p-value } \\
\text { OR } \\
\text { CI } \\
\end{array}$} \\
\hline & \multicolumn{2}{|c|}{ Preterm $(5430)$} & \multicolumn{2}{|c|}{ Full-term (53878) } & \\
\hline & No. & $\%$ & No. & $\%$ & \\
\hline $\begin{array}{l}\text { Nationality } \\
\text { Qatari* } \\
\text { Non-Qatari } \S\end{array}$ & $\begin{array}{l}1796 \\
3634 \\
\end{array}$ & $\begin{array}{c}10.5 \\
8.6 \\
\end{array}$ & $\begin{array}{l}15319 \\
38559 \\
\end{array}$ & $\begin{array}{l}91.4 \\
89.5 \\
\end{array}$ & $\begin{array}{c}\mathrm{p}<0.0001 \\
\mathrm{OR}=0.8 \\
\mathrm{CI}=0.75-0.85\end{array}$ \\
\hline $\begin{array}{l}\text { Mother's occupation } \\
\text { Full-time worker§ } \\
\text { Part-time worker§ } \\
\text { Housewife* }\end{array}$ & $\begin{array}{c}1646 \\
18 \\
2519 \\
\end{array}$ & $\begin{array}{l}9.6 \\
8.7 \\
7.9 \\
\end{array}$ & $\begin{array}{c}15556 \\
188 \\
29355 \\
\end{array}$ & $\begin{array}{l}90.4 \\
91.3 \\
92.1 \\
\end{array}$ & $\begin{array}{c}\mathrm{p}<0.001^{*} \\
\mathrm{OR}=1.23 \\
\mathrm{CI}=1.15-1.31\end{array}$ \\
\hline $\begin{array}{l}\text { High risk pregnancy } \\
\text { Yes§ } \\
\text { No* }\end{array}$ & $\begin{array}{l}1335 \\
4106\end{array}$ & $\begin{array}{l}12 \\
8.5\end{array}$ & $\begin{array}{c}9790 \\
44214\end{array}$ & $\begin{array}{c}88 \\
91.5\end{array}$ & $\begin{array}{c}\mathrm{p}<0.001 * \\
\mathrm{OR}=1.47 \\
\mathrm{CI}=1.37-1.578\end{array}$ \\
\hline $\begin{array}{l}\text { Conception mode } \\
\text { Assisted } \S \\
\text { Spontaneous* }\end{array}$ & $\begin{array}{c}854 \\
3851\end{array}$ & $\begin{array}{c}38.5 \\
8.6\end{array}$ & $\begin{array}{c}1362 \\
41147\end{array}$ & $\begin{array}{l}61.5 \\
91.4\end{array}$ & $\begin{array}{c}\mathrm{p}<0.0001^{*} \\
\mathrm{OR}=6.67 \\
\mathrm{CI}=6.11-7.34\end{array}$ \\
\hline $\begin{array}{l}\text { Place of Delivery } \\
\text { Women's hospital* } \\
\text { Other hospital§ }\end{array}$ & $\begin{array}{c}4813 \\
623\end{array}$ & $\begin{array}{l}9.6 \\
6.9\end{array}$ & $\begin{array}{c}45582 \\
8358\end{array}$ & $\begin{array}{l}90.4 \\
93.1\end{array}$ & $\begin{array}{c}\mathrm{p}<0.001^{*} \\
\mathrm{OR}=1.1 \\
\mathrm{CI}=1.299-1.544\end{array}$ \\
\hline $\begin{array}{l}\text { Antenatal care (ANC) } \\
\text { Yes* } \\
\text { No§ }\end{array}$ & $\begin{array}{c}4775 \\
576 \\
\end{array}$ & $\begin{array}{c}8.6 \\
15.9 \\
\end{array}$ & $\begin{array}{c}50642 \\
3055 \\
\end{array}$ & $\begin{array}{l}91.4 \\
84.1 \\
\end{array}$ & $\begin{array}{c}\mathrm{p}<0.0001^{*} \\
\mathrm{OR}=2.0 \\
\mathrm{CI}=1.82-2.196 \\
\end{array}$ \\
\hline $\begin{array}{l}\text { Father's education } \\
\text { Illiterate \& Elementary } \\
\text { high school/University or above* }\end{array}$ & $\begin{array}{c}265 \\
3037 \\
\end{array}$ & $\begin{array}{l}8.8 \\
7.8\end{array}$ & $\begin{array}{c}2749 \\
36334 \\
\end{array}$ & $\begin{array}{l}91.2 \\
92.2 \\
\end{array}$ & $\begin{array}{c}\mathrm{p}=0.03^{*} \\
\mathrm{OR}=0.87 \\
\mathrm{CI}=0.76-0.998\end{array}$ \\
\hline $\begin{array}{l}\text { Consanguinity } \\
\text { Yes§ } \\
\mathrm{No}^{*}\end{array}$ & $\begin{array}{c}979 \\
2329\end{array}$ & $\begin{array}{l}7.4 \\
8.1\end{array}$ & $\begin{array}{l}12290 \\
26592\end{array}$ & $\begin{array}{l}92.6 \\
91.9\end{array}$ & $\begin{array}{c}\mathrm{p}=0.017 \\
\mathrm{OR}=0.9 \\
\mathrm{CI}=0.8-0.98\end{array}$ \\
\hline $\begin{array}{l}\text { Gravidity } \\
0-3^{*} \\
\text { High gravidity }(>3)\end{array}$ & $\begin{array}{l}3510 \\
1927\end{array}$ & $\begin{array}{c}9 \\
9.4\end{array}$ & $\begin{array}{l}35419 \\
18564\end{array}$ & $\begin{array}{c}91 \\
90.6\end{array}$ & $\begin{array}{c}\mathrm{P}<0.0001 \\
\mathrm{OR}=0.54 \\
\mathrm{CI}=0.51-0.58\end{array}$ \\
\hline $\begin{array}{l}\text { Smoking } \\
\text { Yes§ } \\
\text { No* }^{*}\end{array}$ & $\begin{array}{c}35 \\
4239\end{array}$ & $\begin{array}{c}11.9 \\
8.4\end{array}$ & $\begin{array}{c}258 \\
46180\end{array}$ & $\begin{array}{l}88.1 \\
91.6\end{array}$ & $\begin{array}{c}\mathrm{p}=0.030 \\
\mathrm{OR}=1.48 \\
\mathrm{CI}=1.03-2.1\end{array}$ \\
\hline
\end{tabular}

* Is the control $\S$ is the exposed. 
Table 2. Non-significant Socio-demographic factors.

\begin{tabular}{|c|c|c|c|c|c|}
\hline \multirow{3}{*}{ Socio-demographic characteristics } & \multicolumn{4}{|c|}{ Birth } & \multirow{3}{*}{$\begin{array}{c}\text { p-value } \\
\text { OR } \\
\text { CI }\end{array}$} \\
\hline & \multicolumn{2}{|c|}{ Preterm } & \multicolumn{2}{|c|}{ Full-term } & \\
\hline & No. & $\%$ & No & $\%$ & \\
\hline $\begin{array}{l}\text { Religion } \\
\text { Muslim* } \\
\text { Christian \&Others } \S\end{array}$ & $\begin{array}{c}2680 \\
106\end{array}$ & $\begin{array}{c}10 \\
10.2\end{array}$ & $\begin{array}{c}25871 \\
917\end{array}$ & $\begin{array}{c}90 \\
89.8\end{array}$ & $\begin{array}{c}\mathrm{p}=0.352 \\
\mathrm{OR}=0.9 \\
\mathrm{CI}=0.7-1.3\end{array}$ \\
\hline $\begin{array}{l}\text { Marital status } \\
\text { Married* } \\
\text { Single, Divorced \& separated } \S\end{array}$ & $\begin{array}{c}4324 \\
369\end{array}$ & $\begin{array}{l}9 \\
9\end{array}$ & $\begin{array}{c}43641 \\
3817\end{array}$ & $\begin{array}{l}91 \\
91\end{array}$ & $\begin{array}{c}\mathrm{p}=0.66 \\
\mathrm{OR}=0.97 \\
\mathrm{CI}=0.87-1.09\end{array}$ \\
\hline $\begin{array}{l}\text { Mother's education } \\
\text { Illiterate \& Elementary } \S \\
\text { high school \&University or above* }\end{array}$ & $\begin{array}{c}348 \\
3027\end{array}$ & $\begin{array}{l}7.9 \\
7.9\end{array}$ & $\begin{array}{c}3872 \\
35442\end{array}$ & $\begin{array}{l}92.1 \\
92.1\end{array}$ & $\begin{array}{c}\mathrm{p}=0.39 \\
\mathrm{OR}=1.05 \\
\mathrm{CI}=0.93-1.1\end{array}$ \\
\hline $\begin{array}{l}\text { Father's occupation } \\
\text { Full-time worker* } \\
\text { Part-time \&Unemployed } \S\end{array}$ & $\begin{array}{c}3205 \\
72\end{array}$ & $\begin{array}{l}7.8 \\
8.1\end{array}$ & $\begin{array}{c}37797 \\
1093\end{array}$ & $\begin{array}{l}92.2 \\
91.9\end{array}$ & $\begin{array}{c}\mathrm{p}=0.87 \\
\mathrm{OR}=0.98 \\
\mathrm{CI}=0.79-1.22\end{array}$ \\
\hline $\begin{array}{l}\text { Father's income } \\
\text { Less than } 10 \text { thousand } \S \\
>10 \text { thousand* }\end{array}$ & $\begin{array}{l}1281 \\
1568 \\
\end{array}$ & $\begin{array}{l}7.7 \\
7.7 \\
\end{array}$ & $\begin{array}{l}15381 \\
18883 \\
\end{array}$ & $\begin{array}{l}92.3 \\
92.3 \\
\end{array}$ & $\begin{array}{c}\mathrm{p}=0.93 \\
\mathrm{OR}=1.0 \\
\mathrm{CI}=0.92-1.083\end{array}$ \\
\hline $\begin{array}{l}\text { Type of house } \\
\text { Shared house } \S \\
\text { Apartment/Villa* }\end{array}$ & $\begin{array}{c}665 \\
2637\end{array}$ & $\begin{array}{l}7.5 \\
7.9\end{array}$ & $\begin{array}{c}8161 \\
30857\end{array}$ & $\begin{array}{l}92.5 \\
92.1\end{array}$ & $\begin{array}{c}\mathrm{P}<0.29 \\
\mathrm{OR}=0.95 \\
\mathrm{CI}=0.87 \text { to } 1.041\end{array}$ \\
\hline $\begin{array}{l}\text { Mother's income } \\
\text { Less than } 10 \text { thousand } \S \\
\quad>10 \text { thousand }\end{array}$ & $\begin{array}{l}592 \\
555\end{array}$ & $\begin{array}{l}8.2 \\
8.7\end{array}$ & $\begin{array}{l}6593 \\
6353 \\
\end{array}$ & $\begin{array}{l}91.8 \\
91.3 \\
\end{array}$ & $\begin{array}{c}\mathrm{p}=0.8 \\
\mathrm{OR}=1.02 \\
\mathrm{CI}=0.9-1.14\end{array}$ \\
\hline $\begin{array}{l}\text { Early childbearing } \\
\text { Mother }<20 \text { yrs } \S \\
\text { Mother } 20+\text { yrs* }\end{array}$ & $\begin{array}{c}138 \\
5303\end{array}$ & $\begin{array}{l}9.8 \\
9.1\end{array}$ & $\begin{array}{c}1276 \\
52728\end{array}$ & $\begin{array}{l}91.2 \\
90.9\end{array}$ & $\begin{array}{c}\mathrm{p}=0.4 \\
\mathrm{OR}=1.07 \\
\mathrm{CI}=0.9-1.2\end{array}$ \\
\hline
\end{tabular}

The significance threshold was defined for $\mathrm{P}<0.05 .95 \%$ Confidence interval (CI) Odds ratio (OR)

The odds ratio (OR), its standard error and 95\% confidence interval are calculated according to Altman (26,27). Test of significance: the P-value is calculated according to Sheskin. (28)

\section{Discussion}

Prematurity is a public health problem worldwide, which can compromise health in adulthood. Every year, there are 15 million (11.1\%) preterm births of all births worldwide; the prevalence of associated factors varies from country to country, however international differences among studies addressing preterm births are likely due to differences in sample size and socio-environmental factors (Figure 1).

It became well recognized that Socio-demographic and preconception/prenatal health factors do affect preterm birth rates [7-11]. The Peristat registry records all preterm births in the state of Qatar. Because our center is a tertiary referral hospital with a Level III NICU, it has relatively more preterm births than other hospitals in the country. The main objective of this study was to determine the socio-economic factors associated with newborns born preterm in State of Qatar. We enrolled 5430 children born preterm and 53,878 born at fullterm. The prevalence of preterm birth was $9 \%$. There were more Qatari women in the preterm group than in non-Qatari $(\mathrm{p}<0.001)$.

In western countries, the frequency of prematurity varies between 5 to $9 \%$ [12], while in Africa, it is estimated to be above $15 \%[13,14]$. In Cameroon, the overall preterm birth rate was $13 \%$ in 2010 while higher (26\%) in tertiary maternity hospitals [15]. The global preterm birth rate has been estimated to be 10 to
$11 \%$, with data available from 107 and 184 countries published in two separate systematic reviews $[16,17]$. Studies conducted in the United States and Australia have also reported similar estimates (9.62\% and $8.6 \%$, respectively) $[18,19]$. In Nepal, the incidence of preterm births was 9.3 per 100 live births [8]. In 2001-2005, A Spanish birth data were provided, of $1,878,718$ newborns (from the National Statistical Bulletin), PTB and LBW prevalence's were higher in Spanish vs. non-Spanish (7.9\% and 3.2\%). Compared with Spanish ones, the lowest risk of PTB was observed in North Africa [20].

In a cross-sectional study using data from 331,449 women who gave birth in Spain during 2015, the preterm birth rate was $6.7 \%$, and the low birth weight rate was $7.3 \%$ [21].

In our study, there were more preterm births in high-risk pregnancies than in the low risk healthy pregnancies (12\% vs. $8 \% \mathrm{p}<0.001)$. Also, there were more smoking women in the preterm group ( $12 \%$ vs. $8 \%, \mathrm{p}=0.030)$.

Mothers with high gravidity tend to be less vulnerable to deliver prematurely in comparison to prime mothers.

Although, education and housing were not of significant impact on preterm birth, housewife mothers as well as mothers get pregnant with no assistance were less likely to deliver prematurely.

Socio-demographic variables typically associated with risky pregnancies (preterm birth and low birth weight) including 


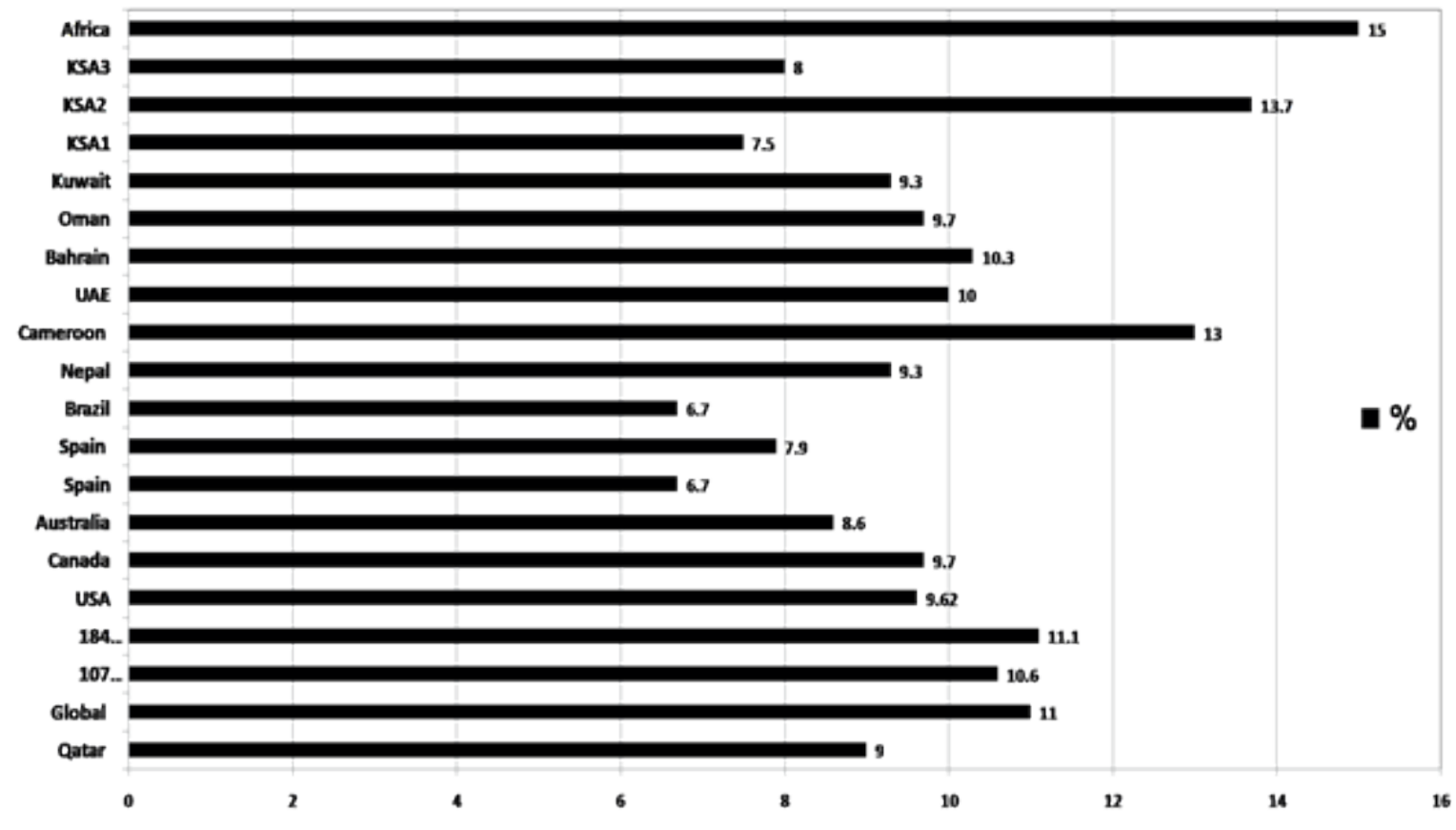

*References: 1,8,13,15,16 171820 21,25-35

Figure 1. Regional and international rate of preterm birth compared to Qatar population*.

maternal age $\leq 19$ years and $\geq 35$ years, an educational level less than secondary studies and single mothers (not having previous children and cesarean births) [22]. In this study, lack of antenatal care was evident in this report and is well documented in the literature as a major risk factor $(15.9 \%$ vs. $8.6 \%, \mathrm{p}<0.0001)[23]$.

Mothers aged less than 20 years are not at higher risk of preterm birth. The mother's level of education was a significant predictor for preterm birth in several literature, and the risk of preterm births was also higher among mothers with education lower than the secondary level [20], this was not observed in our report. Instead, housewives were less vulnerable. In a recent Canadian study, the preterm birth rate was $9.7 \%$, elaborating less impact of maternal education status on birth outcomes. However, low maternal education increased the likelihood of LBW newborns [24]. The seasonal variation of PTB might differ in developing versus developed countries, although our data did examined this factor as seasonal variation is minimal in State of Qatar. In developed countries, the preterm birth rate peaks twice per year (once in the summer and again in winter) (25).

There were more risk factors in our study as, working mothers, lack of antenatal care and assisted conception. We detected no impact of religion, level of maternal education, family income, maternal age and early childbearing. Although this study is superior to similar reports from neighboring Gulf countries - because of its larger sample size and inclusion of all country deliveries and districts, our study has some limitations. First, we did not analyze some of the risk factors (e.g., previous medical history, previous preterm births, cervical length, body mass index, and infection during pregnancy). Nevertheless, this is the first study addressing the impact of socioeconomic factors on the maternal birth outcome in Qatar.

\section{Conclusion}

This report do raise significant concern regarding the impact of antenatal follow up, working mothers, and assistant delivery on the rate of preterm birth.

\section{Acknowledgments}

Qatar National research fund, for its support, to produce and fund such a wealthy maternal-newborn-registry in State of Qatar.

\section{References}

1. Liu L, Johnson HL, Cousens S, et al. Global, regional, and national causes of child mortality: an updated systematic analysis for 2010 with time trends since 2000 [published correction appears in Lancet. 2012 Oct 13;380(9850):1308]. Lancet. 2012;379(9832):2151-2161.

2. Buitendijk S, Zeitlin J, Cuttini M, Langhoff-Roos J, Bottu J. Indicators of fetal and infant health outcomes. Eur J Obstet Gynecol Reprod Biol. 2003;111 Suppl 1:S66-S77.

3. Goldenberg RL, Hauth JC, Andrews WW. Intrauterine infection and preterm delivery. N Engl J Med. 2000;342(20):1500-1507.

4. Kerkhof GF, Breukhoven PE, Leunissen RW, Willemsen RH, Hokken-Koelega AC. Does preterm birth influence cardiovascular risk in early adulthood?. J Pediatr. 2012;161(3):390-396.e1.

5. Romero R, Dey SK, Fisher SJ. Preterm labor: one syndrome, many causes. Science. 2014;345(6198):760-765.

6. CDC. (2015). Candidiasis [Online]. Available: http://www.cdc. gov/fungal/diseases/candidiasis/index.html (Accessed 2015). 
7. Organization WH. Born Too Soon: The Global Action Report on Preterm Birth WHO Press, World Health Organization, 20 Avenue Appia, 1211 Geneva 27, Switzerland.; 2012.

8. Gurung A, Wrammert J, Sunny AK, et al. Incidence, risk factors and consequences of preterm birth - findings from a multicentric observational study for 14 months in Nepal. Arch Public Health. 2020;78:64.

9. Mah E, Sap SNU, Ngwanou DH, et al. Relationship between prematurity, high blood pressure and kidney injury. J Pediatr Neonatal Care. 2020;10(4):104-108

10. Blencowe $\mathrm{H}$, Cousens S, Oestergaard MZet al. National, regional, and worldwide estimates of preterm birth rates in the year 2010 with time trends since 1990 for selected countries: a systematic analysis and implications. Lancet. 2012; 379(9832):2162-2172.

11. Thoma ME, Drew LB, Hirai AH, Kim TY, Fenelon A, Shenassa ED. Black-White Disparities in Preterm Birth: Geographic, Social, and Health Determinants. Am J Prev Med. 2019; 57(5):675-686.

12. Liu L, Oza S, Hogan D, et al. Global, regional, and national causes of under-5 mortality in 2000-15: an updated systematic analysis with implications for the sustainable development goals. Lancet. 2016;388(10063):3027-3035.

13. Balaka $B$, Baeta $S$, Agbèrè $A D$, et al. Facteurs De Risque Associés A La Prématurité Au Chu De Lomé, Togo. Bull Soc Pathol Exot. 2002;95(4):280-283.

14. Sanou I, Traoré A, Kam KL, et al. Morbidité et mortalité néonatales au centre hospitalier universitaire Yalgado Ouédraogo de Ouagadougou (Burkina Faso) de 1993 à 1997. Burkina Médical. 1998;2:18-22.

15. Chiabi A, Mah EM, Mvondo N, et al. Risk factors for preterm births: a cross-sectional analysis of hospital records in a cameroonian health facility. Afr J Reprod Health. 2013;17(4):7783.

16. March of dimes, P mnch. Save the Children. Who. Born Too Soon: The global action report on preterm birth. Geneva: World Health Organization; 2012.

17. Chawanpaiboon S, Vogel JP, Moller AB, et al. Global, regional, and national estimates of levels of preterm birth in 2014: a systematic review and modelling analysis. Lancet Glob Health. 2019;7(1):e37-e46.

18. Purisch SE, Gyamfi-Bannerman C. Epidemiology of preterm birth. Semin Perinatol. 2017;41: 387-391.
19. Kildea SV, Gao Y, Rolfe M, Boyle J, Tracy S, Barclay LM. Risk factors for preterm, low birthweight and small for gestational age births among Aboriginal women from remote communities in northern Australia. Women Birth. 2017;30(5): 398-405.

20. Agudelo-Suárez AA, Ronda-Pérez E, Gil-González D, GonzálezZapata LI, Regidor E. Relación en España de la duración de la gestación y del peso al nacer con la nacionalidad de la madre durante el período 2001-2005 [Relationship in Spain of the length of the gestation and the birth weight with mother's nationality during the period 2001-2005]. Rev Esp Salud Publica. 2009;83(2):331-337.

21. Hidalgo-Lopezosa P, Jiménez-Ruz A, Carmona-Torres JM, Hidalgo-Maestre M, Rodríguez-Borrego MA, López-Soto PJ. Sociodemographic factors associated with preterm birth and low birth weight: A cross-sectional study. Women Birth. 2019;32(6):e538-e543.

22. Kc A, Wrammert J, Nelin V, Ewald U, Clark R, Målqvist M. Level of mortality risk for babies born preterm or with a small weight for gestation in a tertiary hospital of Nepal. BMC Public Health. 2015;15(1):877.

23. Jarde A, Lutsiv O, Park CK, et al. Preterm birth prevention in twin pregnancies with progesterone, pessary, or cerclage: a systematic review and meta-analysis. BJOG. 2017;124:1163-1173.

24. Purisch SE, DeFranco EA, Muglia LJ, Odibo AO, Stamilio DM. Preterm birth in pregnancies complicated by major congenital malformations: a population-based study. Am J Obstet Gynecol. 2008;199(3):287.e1-287.e8.

25. Campbell EE, Gilliland J, Dworatzek PDN, Vrijer BD, Penava D, Seabrook JA. Socioeconomic status and adverse birth outcomes: a population-based canadian sample J Biosoc Sci. 2018; 50(1):102-113.

26. Lee SJ, Filippi SV. Seasonal patterns and preterm birth: a systematic review of the literature and an analysis in a Londonbased cohort. BJOG November 2006;113(11):1280-128

27. Altman DG. Practical statistics for medical research. London: Chapman and Hall. 1991.

28. Altman DG, Deeks JJ, Sackett DL. Odds ratios should be avoided when events are common [letter]. BMJ 1998;3 17:1318.

29. Sheskin DJ. Handbook of parametric and nonparametric statistical procedures. (3rd edtn). Boca Raton: Chapman \& Hall /CRC. 2004. 